\title{
Individualized unsupervised exercise programs and chest physiotherapy in children with cystic fibrosis
}

\section{Bogdan ALMĂJAN-GUȚĂ ${ }^{1}$, Ornela CLUCI ${ }^{2}$, Alexandra RUSU ${ }^{3}$, Oana CIUCA ${ }^{4}$}

\begin{abstract}
Traditionally, physiotherapy for cystic fibrosis focused mainly on airway clearance (clearing mucus from the lungs). This still makes up a large part of daily treatment, but the role of the physiotherapist in cystic fibrosis has expanded to include daily exercise, inhalation therapy, posture awareness and, for some, the management of urinary incontinence. The purpose of this study is to demonstrate the necessity and the efficiency of various methods of chest physiotherapy and individualized unsupervised exercise program, in the improvement of body composition and physical performance. This study included 12 children with cystic fibrosis, with ages between 8 13 years. Each subject was evaluated in terms of body composition, effort capacity and lower body muscular performance, at the beginning of the study and after 12 months. The intervention consisted in classic respiratory clearance and physiotherapy techniques $(5$ times a week) and an individualized unsupervised exercise program ( 3 times a week). After 12 months we noticed a significant improvement of the measured parameters: body weight increased from $32.25 \pm 5.5$ to $33.53 \pm 5.4 \mathrm{~kg}(\mathrm{p}<0.001)$, skeletal muscle mass increased from a mean of $16.04 \pm 4.1$ to $17.01 \pm 4.2(p<0.001)$, the fitness score, increased from a mean of $71 \pm 3.8$ points to $73 \pm 3.8$, $(p<0.001)$ and power and force also registered positive evolutions (from $19.3 \pm 2.68$ to $21.65 \pm 2.4 \mathrm{~W} / \mathrm{kg}$ and respectively $19.68 \pm 2.689$ to $20.81 \pm 2.98 \mathrm{~N} / \mathrm{kg}$ ). The association between physiotherapy procedures and an individualized (after a proper clinical assessment) unsupervised exercise program, proved to be an effective, relatively simple and accessible (regardless of social class) intervention.
\end{abstract}

Key words: cystic fibrosis, body composition, unsupervised exercise program, lower limb power and force.

\section{Rezumat}

În mod tradițional, rolul terapeutului în fibroza chistică viza în principal clearance-ul căilor respiratorii. Acesta încă reprezintă o mare parte a tratamentului de zi cu zi, dar rolul terapeutului s-a extins, iar astăzi protocolalele de interventie includ exercitii zilnice, terapie inhalatorie, conștientizare posturală și, pentru unii, gestionarea incontinenței urinare. Scopul acestui studiu este de a demonstra necesitatea și eficiența diferitelor metode de fizioterapie alături de un program de exercitii individualizat nesupravegheat, la îmbunătățirea compoziției corporale și performanței fizice. Acest studiu a inclus 12 copii cu FC, cu vârste cuprinse între 8 și 13 ani. Fiecare subiect a fost evaluat din punct de vederea al compoziției corporale, capacității de efort și performanței musculare la nivelul trenului inferior, (la inceputul studiului și după 12 luni) .Intervenția a constat în aplicarea tehnicilor clasice de fizioterapie și clearance respirator (de 5 ori pe săptămână) și un program de exercitii individualizat nesupravegheat (de 3 ori pe săptămână). După 12 luni, am observat o îmbunătătire semnificativă a parametrilor măsurați: greutatea corporală a crescut de la 32,25 $\pm 5,5$ la $33,53 \pm 5,4 \mathrm{~kg}$ ( $p<0,001)$, masa musculară scheletală a crescut de la o medie de la 16,04 $\pm 4,1$ la 17,01 $\pm 4,2 \mathrm{~kg}$ ( $p<0,001)$, scorul de fitness a crescut de la o medie de $71 \pm 3,8$ puncte, la $73 \pm 3,8$ ( $p<0,001$ ), iar puterea și forța au înregistrat, de asemenea, evoluții

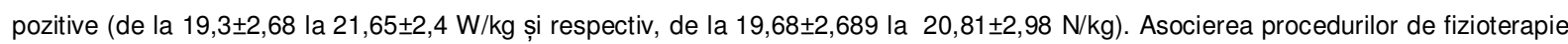
cu un program de exerciții individualizat (după o evaluare clinică adecvată ) chiar și nesupravegheat, s-a dovedit a fi o metodă eficientă, relativ simplu de aplicat si accesibilă indiferent de clasa socială.

Cuvinte cheie: fibroză chistică, compoziție corporală, program de exercitii nesupravegheat, performanța musculară la nivelul trenului inferior.

\footnotetext{
${ }^{1}$ Lecturer PhD, Universitatea Politehnica din Timişoara, e-mail: bogdan.almajan@efs.upt.ro

${ }^{2}$ Physical therapist

${ }^{3}$ Assistant, PHD, West University of Timișoara, Faculty of Physical Education and Sports,

${ }^{4}$ Assistant PhD, Victor Babeș Medicine and Pharmacy University of Timișoara, Faculty of Medicine
} 


\section{Background}

Since the first description of the cystic fibrosis (CF), impaired nutritional status was described as a common situation and a matter of concern for this category of patients (1).

Since then, due to the development of care protocols (that included new-generation antibiotics, individualised chest physiotherapy and improvement in dietary approch), both life expectancy and quality of life increased (1).

The physiotherapy program must be specifically tailored to the needs and preferences of the patients (especially when working with children), so that compliance for therapy is as high as possible.

Traditionally, physiotherapy for cystic fibrosis focused mainly on airway clearance (clearing mucus from the lungs). This still makes up a large part of daily treatment, but the role of the physiotherapist in cystic fibrosis has expanded to include daily exercise, inhalation therapy, posture awareness and, for some, the management of urinary incontinence. We consider that it is very important for their long term well being to develop a good individualized unsupervised exercise program in addition to the bronchial secretions clearance, both due to its efficiency and to the fact that it is less expensive than the other components of the therapeutic strategy and it is accessible at any socio-economic level.

The purpose of this study is to demonstrate the necessity and the efficiency of various methods of chest physiotherapy associated with an individualized unsupervised exercise program, to the improvement of body composition and physical performance.

\section{Material and Method}

This study represents a part of the T.E_ 36 research grant from CNCSIS Romania, Contract No. 13/09.08.2010, and was conducted by the "Politehnica" University from Timisoara in colaboration with the Romanian National Cystic Fibrosis Center.

The study included 12 CF children with ages between 8-13 years.

The work methodology was conceived according to the patients' age group, personal body profile and respecting the physiotherapy protocols accepted on an international level by various physiotherapy groups $(2,3)$.
The evaluation consisted in the assessment of body composition, effort capacity and muscular performance at the beginning of the study and after 12 months, with the help of In-Body 720 device, (South Korea) and Myotest PRO device.

6-minute walk test (6MWT) was used for functional exercise capacity evaluation.

We measured lower limbs Power (W/kg) and Force $(\mathrm{N} / \mathrm{kg})$ with countermovement jump test (CMJ) and squad jump test (SJ), using the myotest device. During the CMJ test, subjects began in an erect standing position with hands on their hips, and moved into a semisquat position before jumping (90 degree leg bend position before immediately jumping up). Hands remain on hips. Each subject performed 5 jumps. During the SJ, subjects began in a standing position with hands on hips and will perform 5 scuad jumps (hands remain on hips).

The intervention consisted in classic respiratory clearance and physiotherapy techniques (5 times a week) and an individualized unsupervised exercise program (3 times a week);

The 30 minutes moderate intensity (70-80 \%) training program was created for each CF patient, after a discussion with the physiotherapist about their particular needs. The unsupervised exercise program was monitored with heart rate monitors (Polar ProTrainer5) and pulsoximeters, taking into account the optimal training heart rate and recovery time after effort, established after the initial testing. Patients were free to select their own physical activity (according to the individual needs and preferences) from a variety of exercises and training models previously presented and practiced with the therapist.

Parents were asked to keep a journal of the physical activity of their children and to present it to the investigator at the next meeting.

The statistical processing of data was made with the help of GraphPad Prism5 statistics program. Data are presented on graphs as mean values.

\section{Results}

After 12 months of intervention, we noticed a significant improvement of the measured parameters: body weight increased from $32.25 \pm 5.5$ to $33.53 \pm 5.4 \mathrm{~kg}(p<0.001)$ (Figure 1$)$, skeletal muscle mass increased from a mean of $16.04 \pm 4$.1 to $17.01 \pm 4.2(p<0.001)$ (Figure 2.), and the fitness 
score, increased from a mean of $71 \pm 3.8$ points to73 $\pm 3.8,(p<0.001)$ (Figure 3.).

The clinical evaluation of our patients revealed an overall good state.

The counter movement jump and squad jump test both demonstrated significant improvements of power and force (from a mean value of $19.3 \pm 2.68$ to $21.65 \pm 2.4 \mathrm{~W} / \mathrm{kg}$ and from $19.68 \pm 2.689$ to $20.81 \pm 2.98 \mathrm{~N} / \mathrm{kg})$.

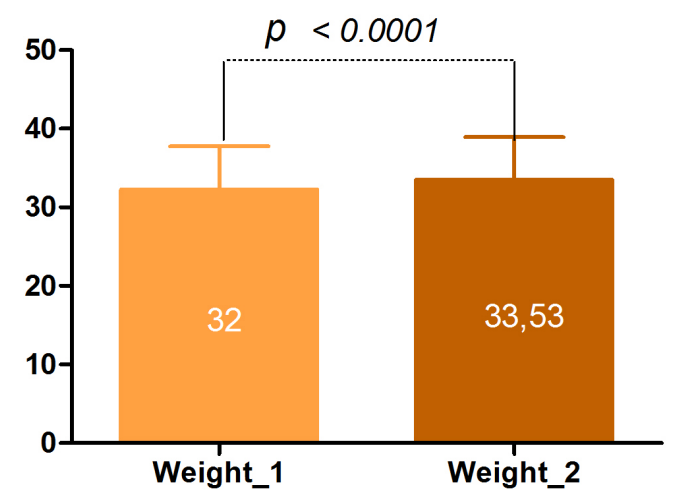

Figure 1. Weight evolution after 12 months of intervention

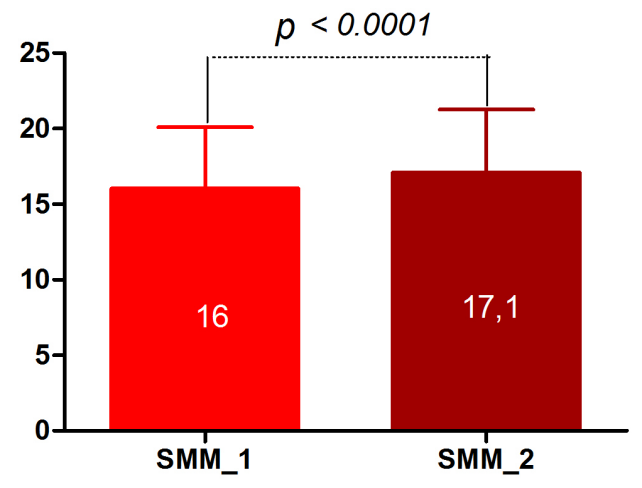

Figure 2. Skeletal muscle mass evolution after 12 months

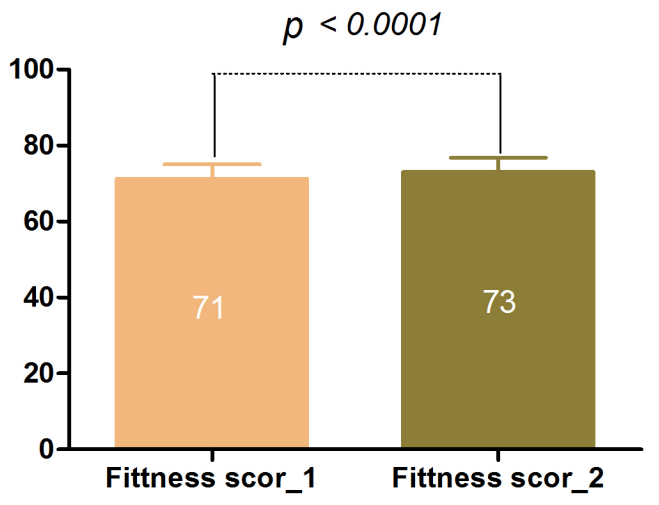

Figure 3. Fitness score evolution after 12 months

\section{Discussions}

Various studies show that children and adolescents with $\mathrm{CF}$ have a reduced tolerance to exercise, and this has a great impact on their well-being and quality of life $(\mathrm{Q} O \mathrm{~L})(4,5,6)$.

A large number of studies also showed that the fitness level is a key predictor of prognosis and mortality in patients with $\mathrm{CF}$, irrespective of factors such as age, sex, lung function and nutritional status $(7,8,9)$.

Some studies reveal improvements in exercise capacity and QoL with supervised physiotherapy and exercise programs, despite of no significant changes in body mass index (BMI) (10).

Our study, (like the above mentioned study) showed that a well established therapy protocol, (including respiratory clearance, physiotherapy techniques and exercise training) can improve effort capacity, power and force but also body composition.

The existing review studies on this subject present limited evidence from both short- and long-term studies about the positive effect of physical training (aerobic or anaerobic). These studies show that improvement in terms of exercise capacity, strength and lungs function are not consistent between studies. Most of the existing short-term studies (which include phisical training) do not show improvement in the CF pacient's condition. This can be explained by the already well known fact, that for these patients weight gain is very difficult and an inappropriate exercise intervention can easily cause side effects like dehydration, muscular damage and even bone fractures (in those with low bone mineral density) (13).

The efficiency of using exercise training to promote physical fitness, well-being and longevity, for this category of patients, seems however to be well understood. A recent survey showed on the other hand that clinicians do not know much about the best way to implement physical exercise in practice, regarding appropriate intensity and duration of the exercise $(11,12,13)$.

Even if supervision is very important for these patients, learning a special program tailored to individual needs, and instructing them about selfmonitoring with heart rate monitors and pulsoximeters (during physical training) may provide 
an effective and convenient alternative for patients and parents/caregivers.

We chose this therapeutic approach for patients living in cities far from the National Cystic Fibrosis Center (located in Timisoara) and which were unable to stay in our facility for a long time or come back very often due to personal or financial problems.

We recommend this type of intervention without forgetting to underline the importance of periodic reassessment and adjustment of therapy.

\section{Conclusion}

Our study showed that a 30-minute moderate intensity, unsupervised training program (followed 3 times/week), combined with the classic physiotherapy intervention for 12 months, can bring significant improvements regarding effort capacity, body composition, strength and power. This intervention proved to be appropriate from the point of view of efficiency, as well as compliance (to the patient and to the family).

Furthermore, physical training is already part of the CF intervention protocol and there is no reason (sustained by the existing studies on this subject) to change this (11).

Further research is needed in order to establish the optimal exercise parameters and the appropriate testing for a correct exercise prescription. (4).

Acknowledgement: This paper work was supported by a research grant from CNCSIS Romania, code TE_36, Contract No. 13/09.08.2010

\section{References}

1. Elborn J.S., Shale D.J., Britton J.R., ( 1991) Cystic fibrosis: current survival and population estimates to the year 2000; Thorax, 46: 881-5;

2. Porter A.E., Young C.S.( 1991) The physiotherapy management of cystic fibrosis in children, Physiotherapy, 75:193-194;

3. Pryor J.A., Webber B.A.( 1992) Physiotherapy for cystic fibrosis: which techniques? Physiotherapy; 78:105-108, (review);

4. Williamsa C.A., Stevens D. (2013) Physical activity and exercise training in young people with cystic fibrosis: Current recommendations and evidence. Journal of Sport and Health Science. Volume 2, Issue 1: 39-46;

5. Stevens D., Oades P.J., Armstrong N., Williams C.A. (2009) Early oxygen uptake recovery following exercise testing in children with chronic chest diseases. Pediatr Pulmonol; 44 pp. 480-488;

6. Stevens D., Oades P.J., Armstrong N., Williams C.A. (2011) Exercise metabolism during moderate-intensity exercise in children with cystic fibrosis following heavy-intensity exercise. Appl Physiol Nutr Metab, 36, pp. 920-927;

7. Nixon P.A, Orenstein D.M., Kelsey S.F., Doershuk C.F. ( 1992) The prognostic value of exercise testing in patients with cystic fibrosis. N Engl J Med; 327(25):1785-8;

8. Moorcroft A.J., Dodd M.E., Webb A.K.( 1997) Exercise testing and prognosis in adult cystic fibrosis. Thorax; 52(3):291-3;

9. Pianosi P., Leblanc J., Almudevar A. ( 2005) Peak oxygen uptake and mortality in children with cystic fibrosis. Thorax; 60(1):50-4;

10. Urquhart D., Sell Z., Dhouleb E., Bell G., Oliver S., Black R. (2012), et al. Effects of a supervised, outpatient exercise and physiotherapy programme in children with cystic fibrosis. Pediatr Pulmonol; 47 pp. 1235-1241;

11. Cystic Fibrosis Trust, Kent (2011) Cystic Fibrosis Trust. Standards for the clinical care of children and adults with cystic fibrosis in the UK. (2nd ed.);

12. American College of Sports Medicine. W.L. Kenny (Ed.), (2000) Guidelines for exercise testing and prescription (6th ed) Lipponcott Williams and Wilkins, Philadelphia;

13. Bradley J.M., Moran F. (2008) Physical training for cystic fibrosis. Cochrane Database of Systematic Reviews, Issue 1. Art. No.:CD002768.DOI: 10.1002/14651858.CD002768. pub2. 